$5^{\text {th }}$ International Conference on Biotechnology Applications in Agriculture (ICBAA), Benha University, 8 April 2021, Egypt (Conference Online)

\title{
Effect of Distillation Period and Storage Conditions on Quality Attributes of Egyptian and Syrian Cumin Essential Oils \\ Ahmed G. Abdel-Haleem ${ }^{1,2}$, Mohamed K. Morsy ${ }^{* 1}$, Raof M. El-Sadany ${ }^{1}$, and Hamdy A. El-Mansy ${ }^{1}$ \\ ${ }^{1}$ Department of Food Technology, Faculty of Agriculture, Benha University, Qaluobia, Egypt. \\ ${ }^{2}$ Pharaonic Essential Oils Company (Phatrade), Obour city, Cairo, Egypt. \\ Corresponding Author: mohamed.abdelhafez@fagr.bu.edu.eg
}

\begin{abstract}
The aim of current study was to evaluate the effect of distillation time and storage conditions up to 12 months on quality and stability of Egyptian and Syrian cumin essential oil. The distillation time were run as 3 fractions $\left(\mathrm{F}_{1}\right.$ : first $6 \mathrm{~h} ; \mathrm{F}_{2}$ : between 7 and $8 \mathrm{~h}$; and $\mathrm{F}_{3}$ : between 9 and $12 \mathrm{~h}$. The stability, physicochemical, and composition of cumin oil at room temperature and refrigerator up to 12 months were evaluated. The results demonstrated that the yield percentage of Egyptian cumin essential oil (ECEO) was (5.59\%) and Syrian cumin essential oil (SCEO) was (3.36\%). The oil produced at first $6 \mathrm{~h}$ of distillation $\left(\mathrm{F}_{1}\right)$ with best quality $(\sim 90 \%)$, followed by $\mathrm{F}_{2}(\sim 7.50 \%)$ and $\mathrm{F}_{3}(2.50 \%)$. The 18 compounds were identified in CEO and the main compounds were cuminaldehydes, $\beta$-pinene, $\beta$-myrcene, $p$ cymene, d-limonene, and $\gamma$-terpinene. In addition, the results demonstrated that storage at different temperature influences on the quality and composition of cumin oil especially at room temperature. During the storage the components i.e. $\alpha$-pinene, $\beta$-pinene, $\beta$-myrcene, $d$-limonene and $\gamma$-terpinene were decreased, while $p$-cymene was increased however, cuminaldehyde increased during 12 months at room temperature compared with refrigerator. The sensory attributes of CEO stored at refrigerator was significantly higher than room temperature. These results confirmed that ECEO is better than SCEO during processing and more stable during storage.
\end{abstract}

Keywords: essential oils, cumin seed, steam distillation, storage stability, quality.

\section{Introduction}

Cumin seed (Cuminum cyminum L.) one of the most commonly ancient spices native to Egypt and Syria, which regularly used as a flavoring agent in food industry (Al-Snafi, 2016). Egypt has a rich history in the production and trade of cumin seeds over the world. Generally, the cumin was utilized in food processing in different forms i.e. whole seeds, crushed, grind, and recently as essential oil (Sowbhagya, et al.; 2008).

Cumin essential oil (CEOs) has well known as generally recognized as safe (GRAS) in food application and medicine. It has widely used in food products such as meat, fish, canned food, pickles, and good products (Teneva, et al., 2016). While, in medicinal sector has utilized as carminative, astringent, stimulant, antispasmodic, sedative, stomachache, antiinflammatory, diuretic, calmative, diarrhea, flatulence, and indigestion.

In addition, CEOs have many benefits i.e. antibacterial, antifungal, and antioxidant activities in food applications (Moghaddam et al., 2015; Aćimović, et al., 2016; and Mehdizadeh, et al., 2017). One study by Ochoa et al., (2014) found that the CEOs have antibacterial activity against $E$. coli $\mathrm{O} 157: \mathrm{H} 7, L$. monocytogenes, S. enterica, Campylobacter jejuni, and S. aureus. Moreover, Viuda-Martos et al. (2008) reported that cumin essential oil was active against Lactobacillus sakei and Enterobacter gergoviae. While, Lacobellis et al., (2005) demonstrated that CEOs more active against $E$. coli (MIC; $1 \mu \mathrm{l} / \mathrm{ml}$ ), while $S$. aureus, and L. monocytogenes had MIC values of 1 and $2 \mu \mathrm{l} / \mathrm{ml}$, respectively. On the other side, Allahghadri et al., (2010) stated the CEOs have higher antioxidant activity compared with that of BHT and BHA.

The CEOs are highly complex mixtures of volatile compounds (Al-Zubairi, et al., 2017). The major components in CEOs are $\beta$-pinene, $p$-cymene, $\gamma$ terpinene, cuminaldehyde, $p$-mentha-dien-7-al, $\quad p$ mentha-1,3-dien-7-al, and p-mentha-1,4-dien-7-al which representative more than $90 \%$ of total oil components (Teneva, et al., 2016; and Ingok and Guler, 2017). In addition, Mehdizadeh et al., (2017) demonstrated that the main effective components group of CEOs are oxygenated monoterpenes compounds, especially aldehydes.

The quality of CEOs is depending on extraction methods, extraction conditions, extraction time, and storage conditions. There are several methods for extraction of CEOs such as steam distillation, hydrodistillation, supercritical fluid extraction (SFF), and organic solvents. Al-Hashemi, (2014) found that steam distillation is the best method for CEOs extraction with high yield. However, Mehdizadeh et al., (2017) demonstrated that storage of CEOs at different temperature affected on oil quality and chemical composition i.e. increased such as cuminaldehyde (oxygenated component) while others decreased like $\beta$ pinene, and $\gamma$-terpinene (monoterpenes).

The aim of this study was to evaluate the effect of distillation time and storage conditions i.e. room temperature $\left(25 \pm 1^{\circ} \mathrm{C}\right)$ and refrigerator $\left(4 \pm 1^{\circ} \mathrm{C}\right)$ up to 12 
months on quality and stability of Egyptian and Syrian cumin essential oil.

\section{Materials and methods:}

\subsection{Materials}

The Egyptian cumin seeds were purchased in season 2016 from Assiute farm, Egypt, while Syrian cumin seeds were purchased from a local market in Cairo, Egypt at the same season. The seeds were transported in a big package $50 \mathrm{~kg}$ for each and stored at ambient temperature $25 \pm 1^{\circ} \mathrm{C}$ until distillation.

\subsection{Chemicals and Reagents}

Methanol, acetonitrile, ethanol, sodium sulfate anhydrous, phenolphthalein, and sodium hydroxide were purchased from Sigma Aldrich Company, Cairo, Egypt. All chemicals and reagents HPLC grade.

\subsection{Extraction of cumin essential oil (CEOs)}

The cumin oil was extracted by steam distillation according to the method described by Guenther (1961) with slight modifications. Briefly, the seeds were soaked in water at $\left(25 \pm 1^{\circ} \mathrm{C} / 8 \mathrm{~h}\right)$, then put into distillation still. The essential oil was extracted by the steam distillation at commercial scale (Boiler, Babcock \&Wilcox, Egypt) at pressure $1 \mathrm{bar}$ for $12 \mathrm{~h}$ at 3 fractions as follows; $\left(\mathrm{F}_{1}\right.$ : first $6 \mathrm{~h}$ of the distillation, $\mathrm{F}_{2}$ : between $7^{\text {th }}$ to $8^{\text {th }} \mathrm{h}$ of distillation, and $F_{3}$ : between $9^{\text {th }}$ to $12^{\text {th }} \mathrm{h}$. The CEOs were condensed and received in the flask, then filtrated using sodium sulfate anhydrous and stored in a refrigerator until analysis.

\subsection{Essential oils storage}

The CEOs were placed into clean and dark glass bottles $(30 \mathrm{~mL})$ and kept at both room temperature $\left(25 \pm 1^{\circ} \mathrm{C}\right)$ and at refrigerator $\left(4 \pm 1^{\circ} \mathrm{C}\right)$. The oil samples were analyzed after $0,3,6$, and 12 months of storage.

\subsection{Physicochemical properties}

The specific gravity was measured by density meter (DMA 35, Graz, Austria) at $20 / 20^{\circ} \mathrm{C}$ according to Baser and Buchbauer (2010). Refractive index was measured using Abbe Refractometer (BAushi \& Lomb, USA) at $20^{\circ} \mathrm{C}$ according to AOAC (2016). Optical rotation was measured by polarimeter (WXG-4 specifications) at wavelength $589.44 \mathrm{~nm}$ according to Baser and Buchbauer (2010). The solubility in alcohol and acid number of CEOs were determined according to the method described by AOAC (2016).

\subsection{GC and GC/MS fingerprint of CEOs}

The composition of the cumin essential oil was determined by GC and GC/MS. The GC equipment was an Agilent Chromatograph (Hewlett packard) HP-5890 series II instrument, with flame ionization detector
(FID) and a capillary column DBF restek, RXI@- $1 \mathrm{~ms}$ (100\%-dimethylpolysiloxan, $30 \mathrm{~m} \times 0.25 \mathrm{~mm}$ i.d., and $0.25 \mu \mathrm{m}$ thickness). The carrier gas was nitrogen at a volumetric flow rate of $1.1 \mathrm{ml} \cdot \mathrm{min}^{-1}$. Analysis was done with a sample quantity of $0.2 \mu$, which was prepared by using acetonitrile HPLC grade, with split ratio 50:1, under the following temperature programmed: initial column temperature $60^{\circ} \mathrm{C}$, hold $5 \mathrm{~min}$, increased to $250^{\circ} \mathrm{C}$ at the rate of $3^{\circ} \mathrm{C} / \mathrm{min}$. the detector (FID) temperature was $280^{\circ} \mathrm{C}$ and the injector temperature was $250^{\circ} \mathrm{C}$ according to Moghaddam et al. (2015). Area percentage of peaks were calculated with software DDS1032.

GC-MS analyses of cumin essential oil samples were performed on an Agilent Technologies 7890B gas chromatograph coupled to an Agilent 5977A, mass selective detector (MSD) and a quadrupole Electron Ionization (EI) mass analyzer. An HP-5MS 5\% column (coated with methyl silicone) $(30 \mathrm{~m} \times 0.25 \mathrm{~mm}, 0.25 \mu \mathrm{m}$ film thicknesses) was used as the stationary phase. Helium was used as the carrier gas at $0.95 \mathrm{~mL} / \mathrm{min}$ flow rate. The temperature programmed was initial temperature $60^{\circ} \mathrm{C}$; hold $2 \mathrm{~min}$, increased to $250^{\circ} \mathrm{C}$ at a $4^{\circ} \mathrm{C} / \mathrm{min}$ ramp rate. The injector and the GC-MS interface temperatures were maintained at $250^{\circ} \mathrm{C}$ and $280^{\circ} \mathrm{C}$, respectively. Mass spectra were recorded at 70 $\mathrm{eV}$. The ion source and the detector temperatures were maintained at 230 and $150^{\circ} \mathrm{C}$, respectively. The samples $(0.5 \mu \mathrm{L})$ were injected neat with a 1:100 split ratio according to Mehdizadeh et al., (2017), with some modification. Compound identification was made from the mass spectra of compounds using Agilent library (wiely9 and nist11 lib.).

\subsection{Sensory evaluation}

The sensory evaluation of essential oil was done according to Atawia et al. (1988). Panelists were chosen from the professional personnel in the Phatrade essential oil company. The panelists given orientation sessions to become familiar with the test procedures and compounds. All testing took place between 9.00 and $11.00 \mathrm{Am}$ at room temperature between $25 \pm 1^{\circ} \mathrm{C}$.

The oil samples were placed into $10 \mathrm{~mL}$ glass bottle, then plugged coded with 3-digit random numbers and allowed to stand at room temperature few minutes prior to evaluation. The panelists were asked to characterize odor and color using nine-point hedonic scale with score being as follows; $1=$ extremely poor or dark brown, $2=$ very poor or brownish yellow, $3=$ poor or slightly brownish yellow, $4=$ below fair or reddish yellow, $5=$ fair or slightly reddish yellow, $6=$ below good or dark yellow, $7=$ good or slightly pale yellow, $8=$ very good or yellow, and $9=$ excellent or pale yellow.

\subsection{Data analysis}


The obtained results were analyzed statistically using one-way ANOVA with a significance level of $\mathrm{P} \leq$ 0.05 using SPSS software, var. 19 (IBM; Armonk, N.Y., U.S.A.). The physical and chemical properties variance was analyzed as a completely randomized design according to Steel and others (1997). All experiments tests were performed in triplicate, using three samples per treatment. Multiple comparisons were carried out applying least significant difference.

\section{Results and discussion}

\subsection{Cumin essential oil extraction and yield}

The extraction of cumin oil using steam distillation was selected due to inexpensive and keeps the fragrance constituents with high yield (Beis et al., 2000). Li, et al., (2009) found that cumin oil extraction by hydrodistillation keeps the quality but give low yield, while extracts by solvents caused chemical pollute of the fragrances, as well, the extraction using supercritical fluid extraction (SFE) was very expensive.

The yield of Egyptian and Syrian cumin essential oil extracted using steam distillation was shown in Table (1). The results demonstrated that the oil yield of Egyptian cumin was higher than Syrian cumin. The yield of Egyptian and Syrian cumin oil were 5.59 and $3.36 \%$, respectively. The increasing in Egyptian cumin oil yield may be due to variety, soil, and climatic conditions. These results were agreement with those reported by Teneva et al. (2016) and Al-Hashemi (2014). While, El-Moshtohory (2007) found that Egyptian cumin seeds contain $3.13 \%$ essential oil. Generally, the Egyptian cumin is the best variety compared with Iranian cumin (1.4- 2.2\%), Indian cumin (3\%), and Tunisian cumin (1.21-1.62\%) (Hashemian et al. 2013; Rana, 2014; Bettaieb et al., 2011).

Furthermore, the yield of Egyptian and Syrian cumin oil at different fractions times were evaluated. A significant difference $(\mathrm{p} \leq 0.05)$ was observed between distillation time and oil yield. In general, the yield of CEOs was decreased during distillation period, thus at the first $6 \mathrm{~h}$ $\left(\mathrm{F}_{1}\right)$, the yield of the Egyptian and Syrian cumin was ( 90.38 and $94.05 \%), F_{2}(7.15$ and $4.46 \%)$, and $F_{3}(2.45$ and $1.49 \%$ ), respectively of total oil yield. The results are partially agreement with those reported by Sowbhagya et al. (2008). These separations in fractions can helps consumers and essential oil producers to use these oils and its compounds in different industries application such as food, medicinal, and cosmetic.

Table 1. Yield percentage of cumin essential oil at different times of distillation.

\begin{tabular}{lcccc}
\hline \multirow{2}{*}{ Cumin origin } & \multicolumn{3}{c}{ Yield (\%) } & \multirow{2}{*}{ Total Yield } \\
\cline { 2 - 4 } & $\left(\mathbf{F}_{\mathbf{1}}\right)$ & $\left(\mathbf{F}_{2}\right)$ & $\left(\mathbf{F}_{3}\right)$ & \\
\hline Egyptian & $5.05 \pm 0.15$ & $0.40 \pm 0.21$ & $0.14 \pm 0.11$ & $5.59 \pm 0.05^{\mathrm{a}}$ \\
Syrian & $3.16 \pm 0.12$ & $0.15 \pm 0.18$ & $0.05 \pm 0.14$ & $3.36 \pm 0.03^{\mathrm{b}}$ \\
\hline
\end{tabular}

$\mathrm{F}_{1}$ : first 6 hours of distillation

$\mathrm{F}_{2}: 7^{\text {th }}-8^{\text {th }}$ hours of distillation

$F_{3}$ : Last $9^{\text {th }}-12^{\text {th }}$ of distillation

abc Values in the same column for each attribute followed by different letters are significantly different $(\mathrm{P}<0.05)$.

Mean $\pm \mathrm{SD}, \mathrm{n}=3$.

\subsection{GC/MS fingerprint of cumin essential oil}

Table (2) and Fig. (1 and 2) showed the chemical composition of the Egyptian and Syrian essential oils analyzed by GC/MS. A total 18 compounds were identified ( 95- 99\% of the total components). The main compounds in CEOs are $\beta$-pinene, $p$-cymene, $\gamma$ terpinene, cuminaldehyde, 3-para menthanal- 7-al, 1,3 para mentha diene -7-al, and 1,4 para mentha diene -7al. Furthermore, the cuminaldehyde is the major component in CEOs. These results were agreement with those reported by Moghaddam et al. (2015) and Mehdizadeh et al. (2017).

Furthermore, the area percentage of CEOs components influences during distillation time (fractions), some of components increased during distillation time such as monoterpene hydrocarbons group, while oxygenated monoterpenes group were decreased during distillation. As well, the main component cuminaldehyde was decreased during distillation time; the $F_{1}$ was highest value compared with $F_{2}$ and $F_{3}$. In addition, the total aldehydes (3-para $>$ menthanal- 7-al, cuminic aldehyde, 1, 3 para mentha diene -7-al and 1, 4 para mentha diene -7-al) of CEOs $\stackrel{\Xi}{*}$ were decreased because the most of aldehydes extracted $>$ at first $6 \mathrm{~h}$ of distillation. In $\mathrm{F}_{1}$ the total aldehydes were 46.49\% in Egyptian cumin essential (ECEO) and $60.51 \%$ in Syrian cumin essential oil (SCEO), however in $\mathrm{F}_{2}$ the total aldehyde were $20.88 \%$ in ECEO and $29.47 \%$ in SCEO, while in $\mathrm{F}_{3}$ was the least value in ECEO to $13.16 \%$ and $17.79 \%$ in SCEO and caused unacceptable smell of cumin oil. These results were matched with those reported by Sowbhagya et al. (2008). 
Time (min)

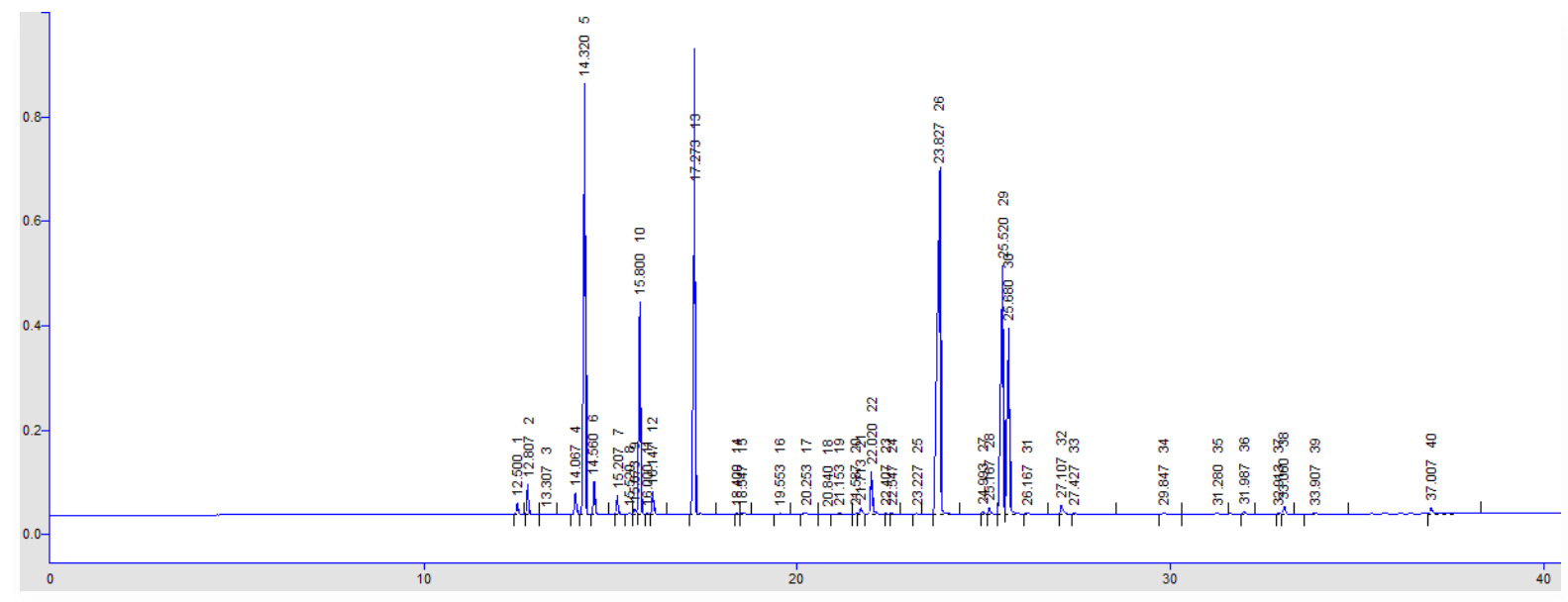

Time (min)

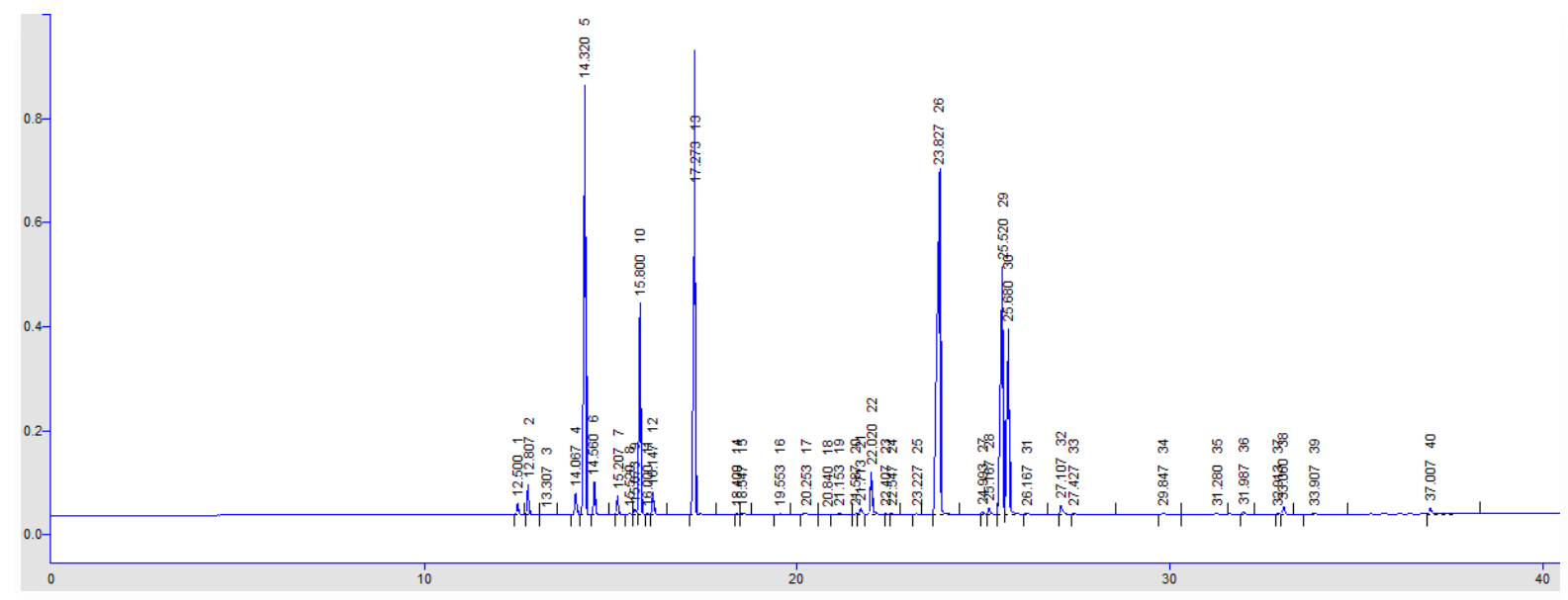

Time (min)

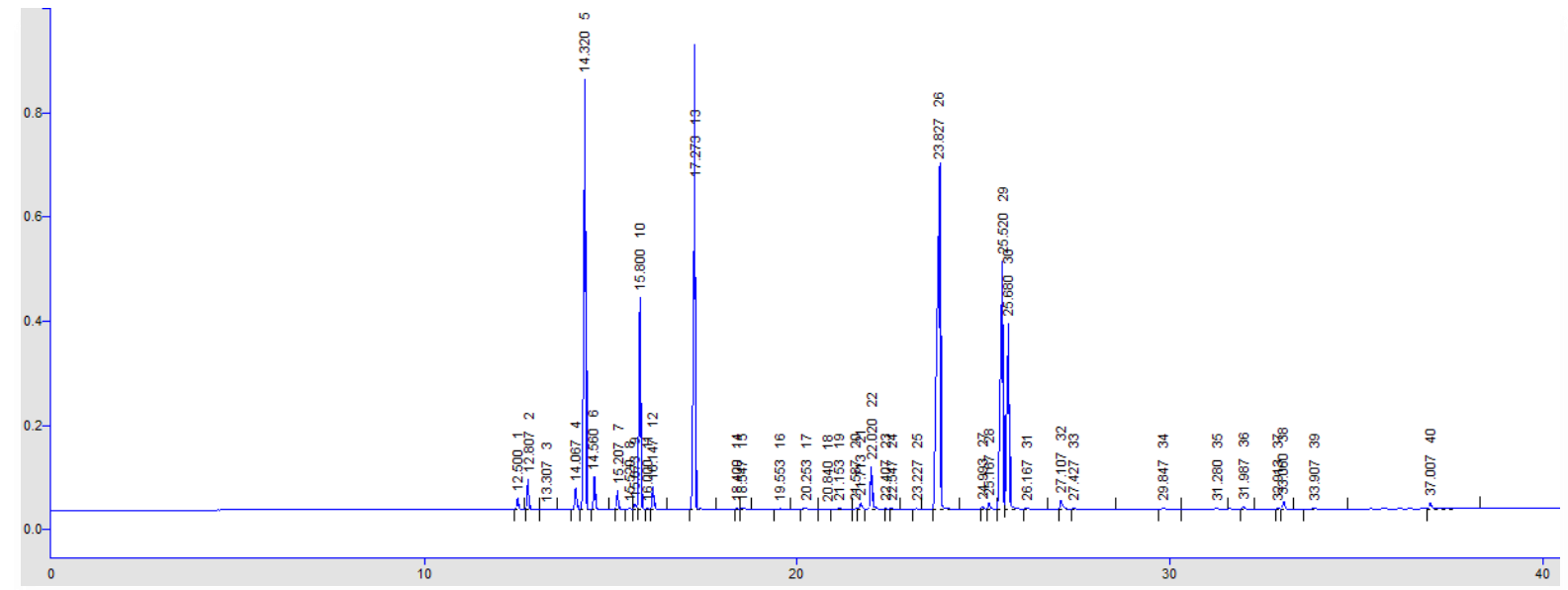

As shown in Fig. (1 and 2) and Table (2), the result demonstrated that, the hydrocarbon terpenes compounds such as $\alpha$-pinene, $\beta$-pinene, $\beta$-myrcene, $p$-cymene, $d$-limonene and 
Figure 1. GC-Volatile compounds of Egyptian cumin essential oil at different extraction time (a) first $6 \mathrm{~h}$, (b) at 7 and $8 \mathrm{~h}$, and (c) from 9 to $12 \mathrm{~h}$.

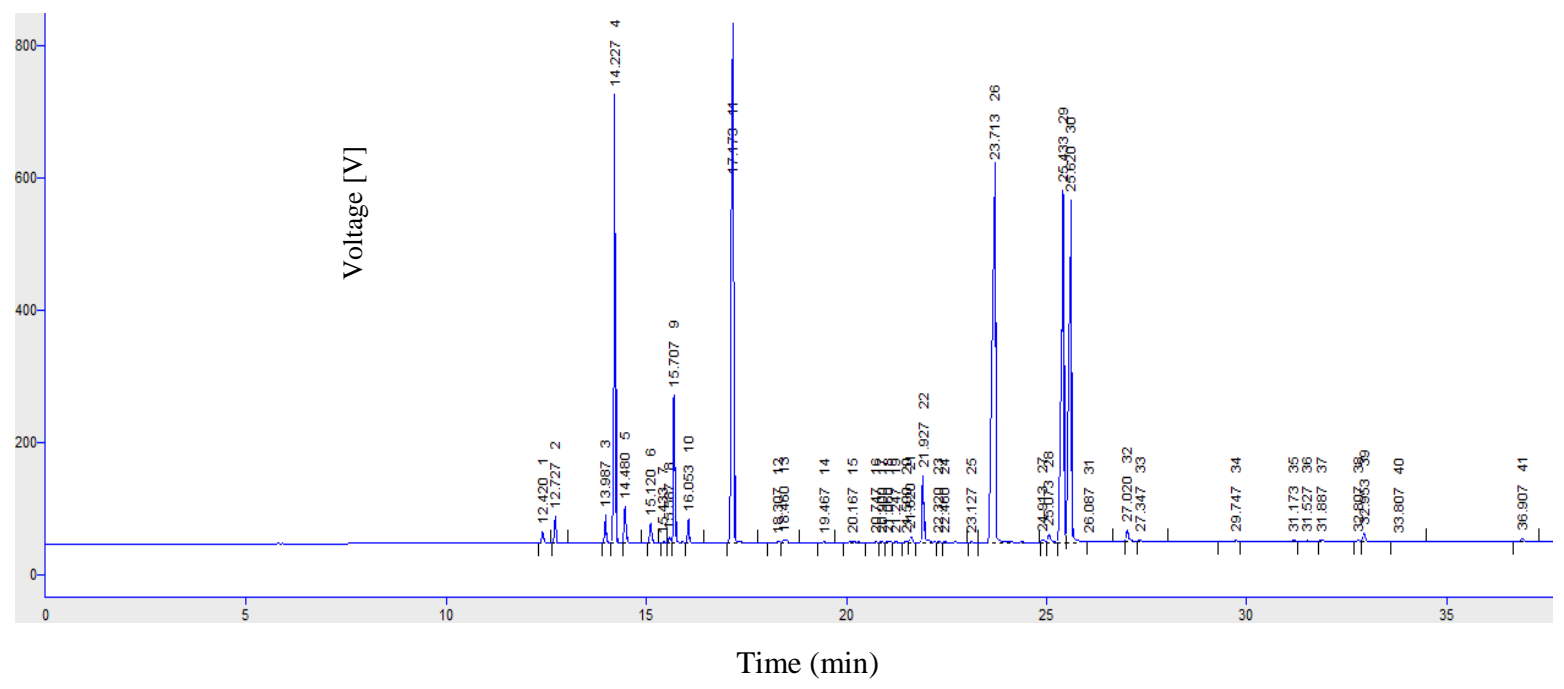

$\mathbf{a}$

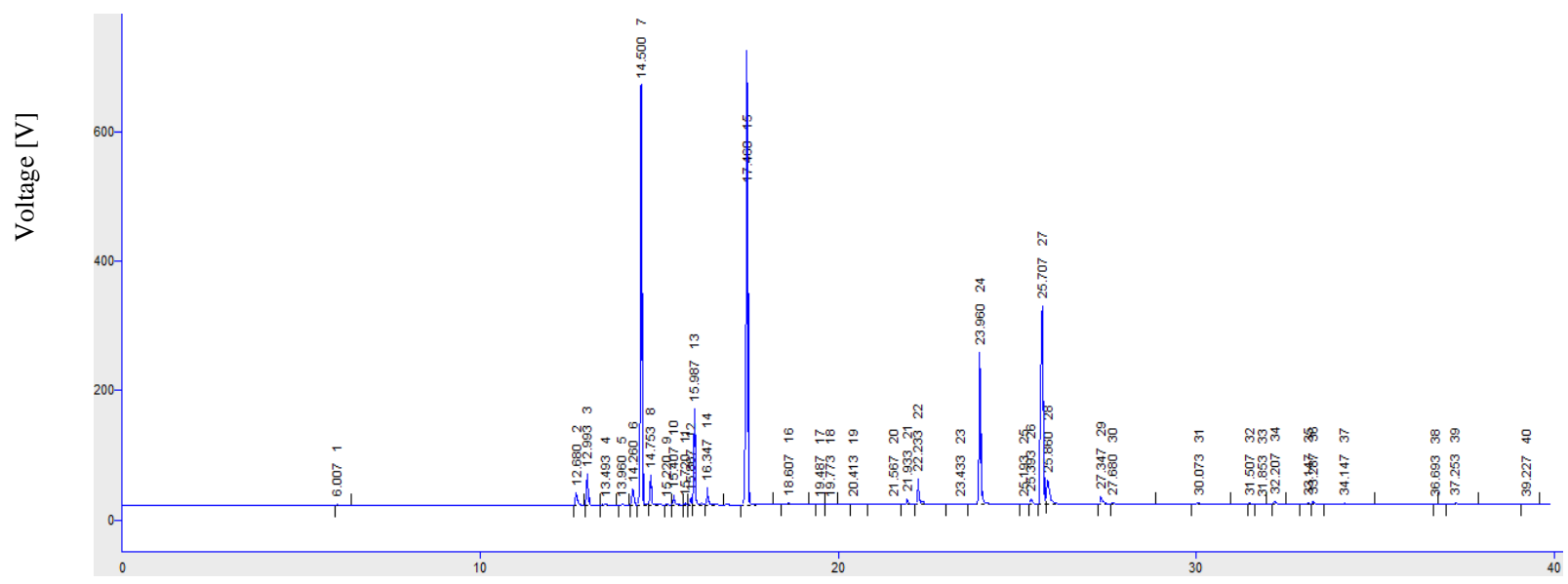

b

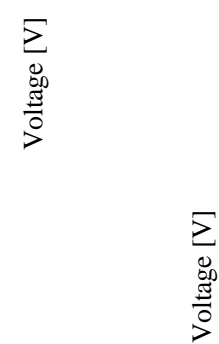

Time (min) 


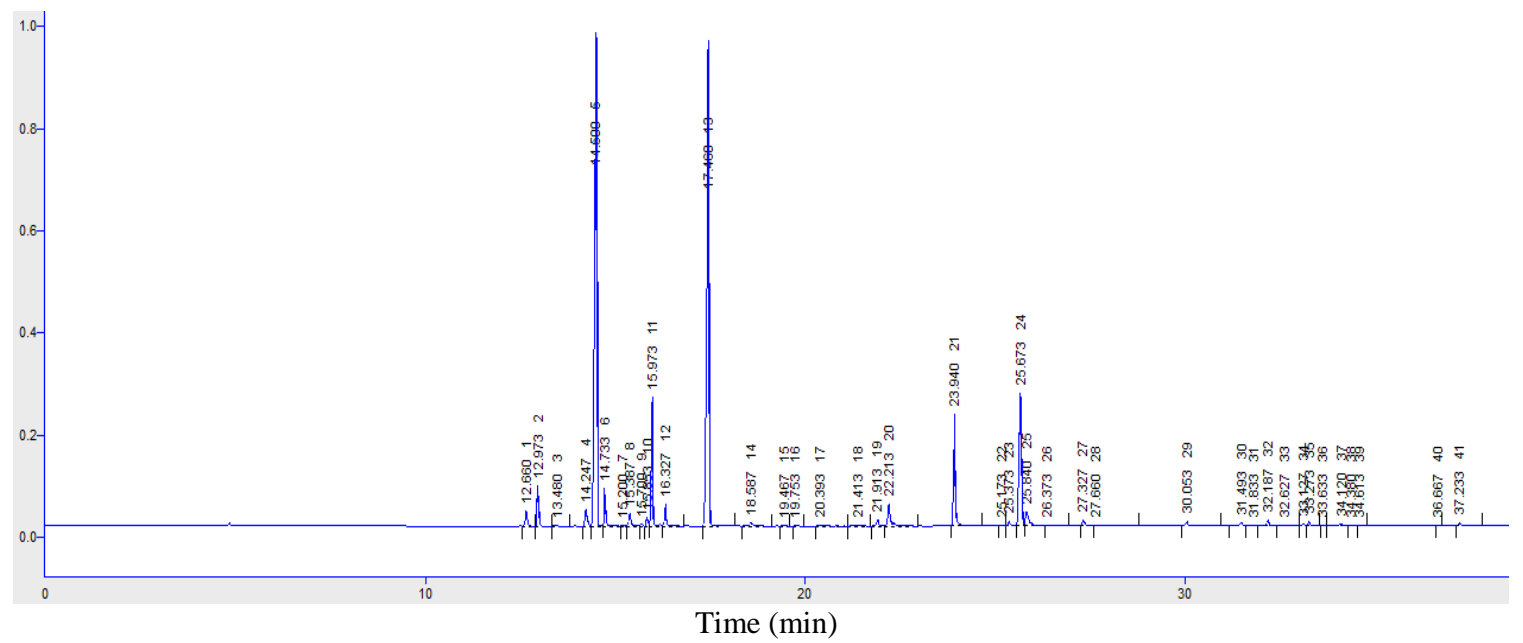

Figure 2. GC-Volatile compounds of Syrian cumin essential oil at different extraction time (a) first $6 \mathrm{~h}$, (b) at 7 and $8 \mathrm{~h}$. and (c) from 9 to $12 \mathrm{~h}$.

Table 2. Volatile compounds of Egyptian and Syrian cumin essential oils at different time of distillation.

\begin{tabular}{|c|c|c|c|c|c|c|c|c|}
\hline \multirow{4}{*}{ No } & \multirow{4}{*}{ Compounds } & \multirow{4}{*}{ RT } & \multicolumn{6}{|c|}{ Area \% } \\
\hline & & & \multicolumn{6}{|c|}{ Distillation time } \\
\hline & & & \multicolumn{3}{|c|}{ Egyptian } & \multicolumn{3}{|c|}{ Syrian } \\
\hline & & & $\mathbf{F}_{1}$ & $F_{2}$ & $\mathbf{F}_{3}$ & $\mathbf{F}_{1}$ & $\mathbf{F}_{2}$ & $\mathbf{F}_{3}$ \\
\hline 1 & Alpha thujene & 12.50 & 0.36 & 0.62 & 0.64 & 0.30 & 0.10 & 0.71 \\
\hline 2 & $\alpha$-Pinene & 12.80 & 0.91 & 1.94 & 2.12 & 0.57 & 1.48 & 1.81 \\
\hline 3 & Sabinene & 14.06 & 0.80 & 0.69 & 0.800 & 0.77 & 0.91 & 0.94 \\
\hline 4 & $\beta$ - pinene & 14.32 & 16.47 & 28.37 & 32.84 & 13.41 & 24.64 & 29.97 \\
\hline 5 & $\beta$ - myrcene & 14.56 & 1.07 & 1.62 & 1.69 & 1.03 & 1.63 & 1.84 \\
\hline 6 & $\alpha$-phellendrene & 15.33 & 0.57 & 0.89 & 1.11 & 0.42 & 0.69 & 1.25 \\
\hline 7 & $P$-cymene & 15.80 & 5.56 & 7.22 & 7.54 & 3.52 & 6.19 & 6.50 \\
\hline 8 & d-Limonene & 16.14 & 0.80 & 1.02 & 1.32 & 0.76 & 1.010 & 1.17 \\
\hline 9 & $\gamma$-terpinene & 17.27 & 21.65 & 33.05 & 33.36 & 17.64 & 30.34 & 34.25 \\
\hline 10 & Linalool & 18.40 & 0.06 & 0.20 & 0.300 & 0.07 & 0.20 & 0.26 \\
\hline 11 & Beta-ocimene & 18.54 & 0.07 & 0.00 & 0.00 & 0.16 & 0.00 & 0.00 \\
\hline 12 & Terpinene - 4- ol & 21.71 & 0.27 & 0.300 & 0.32 & 0.25 & 0.37 & 0.38 \\
\hline 13 & 3-para menthanal- 7-al & 22.02 & 1.74 & 1.36 & 1.14 & 2.40 & 1.91 & 1.52 \\
\hline 14 & Cuminaldehyde & 23.82 & 22.74 & 8.47 & 5.59 & 18.96 & 10.61 & 6.76 \\
\hline 15 & 1,3 para mentha diene -7 -al & 25.52 & 13.01 & 8.09 & 3.93 & 19.57 & 14.00 & 8.05 \\
\hline 16 & 1,4 para Mentha diene -7 -al & 25.68 & 9.00 & 2.96 & 2.50 & 19.58 & 2.95 & 1.46 \\
\hline 17 & Cuminol & 27.10 & 0.45 & 0.78 & 0.35 & 0.04 & 0.77 & 0.46 \\
\hline 18 & $\beta$-caryophellene & 33.06 & 0.28 & 0.41 & 0.55 & 0.24 & 0.19 & 0.24 \\
\hline \multicolumn{9}{|c|}{ Grouped components (\%) } \\
\hline & Monoterpene hydrocarbons & & 48.19 & 75.42 & 81.42 & 38.42 & 66.99 & 78.44 \\
\hline & Oxygenated monoterpenes & & 47.28 & 21.96 & 13.83 & 60.96 & 30.61 & 18.63 \\
\hline & Others & & 0.28 & 0.41 & 0.55 & 0.24 & 0.19 & 0.24 \\
\hline \multicolumn{9}{|c|}{ Total aldehydes (\%) } \\
\hline & Total aldehyde & & 46.49 & 20.88 & 13.16 & 60.51 & 29.47 & 17.79 \\
\hline \multicolumn{9}{|c|}{ Total identified compounds (\%) } \\
\hline & Total & & 95.81 & 97.99 & 96.10 & 99.69 & 97.99 & 97.57 \\
\hline
\end{tabular}

$\mathrm{F}_{1}$ : first 6 hours of distillation

$F_{2}: 7^{\text {th }}-8^{\text {th }}$ hours of distillation

$\mathrm{F}_{3}$ : Last $9^{\text {th }}-12^{\text {th }}$ of distillation

RT: Retention time 
$\gamma$-terpinene were increased during distillation time. The $\mathrm{F}_{3}$ was the highest value compared $\mathrm{F}_{2}$ and $\mathrm{F}_{1}$ respectively. These variations caused undesirable odor in oil and low quality.

From abovementioned results, the fraction technique is the best way for CEOs extraction, because it gives options to manage and control of the proportions of CEOs (addition and/or deletion).

\subsection{Physical and chemical properties of cumin essential oil fractions}

The effect of distillation in fractions on physical and chemical properties of the CEOs was evaluated. As shown in Table (3) the physical and chemical properties of CEOs influence by distillation time. Results demonstrated that specific gravity and refractive index for Egyptian and Syrian cumin oils were decreased in $\mathrm{F}_{2}$ and $F_{3}$ than $F_{1}$, this due to high concentration of terpenes (low in molecular weight) and low concentration of aldehydes (high molecular weight). Whereas, the optical rotation in ECEO was decreased while SCEO increased during distillation time, may be due to environmental conditions. On the other hand, the acid number was increased during distillation time because of high concentration of oil terpenes that causes oil oxidation and gives indicator of oil degradation (Saha et al., 2016).

\subsection{Storage stability of cumin essential oil}

There are few researches on the storage conditions of essential oils (Mehdizadeh et al., 2017). The storage of CEOs at room temperature and refrigerator up to 12 months was shown in Table (4 and 5) and Fig. (3 and 4). The decreasing in $\alpha$-pinene, $\beta$-pinene, $\beta$-myrcene, $\gamma$ terpinene and d-limonene, as well, the increasing in $p$ cymene, given an indicator for cumin essential oil degradation and low quality with an unacceptable odor. Moreover, the best odor of CEOs were found when area percentage of cuminaldehyde ranged between 18-26\% and total aldehyde between $45-55 \%$.

The result showed in Table (4 and 5) and Fig. (3 and 4), indicate that the concentration of components with a low molecular weight such as $\alpha$-pinene, $\beta$ pinene, $\beta$-myrcene, $\gamma$-terpinene and $\mathrm{d}$-limonene decreased gradually with storage time especially at room temperature, due to evaporation or degradation of these components with time. These results agreement with Mehdizadeh et al., (2017). While, p-cymene was increased at room temperature than refrigerator condition, due to oil oxidation and/or deterioration. This result contrary with those found by Mehdizadeh $\boldsymbol{e t}$ al., (2017).

Moreover, the CEOs after 12 months of storage at room temperature and refrigerator, the concentration of $\beta$-pinene decreased in ECEO from $16.47 \%$ to $12.57 \%$ and $15.99 \%$, with decreased ratio $23.68 \%$ and $2.91 \%$, respectively. While SCEO decreased from $13.41 \%$ to $9.26 \%$ and $12.29 \%$, with decreased ratio $30.94 \%$ and $8.35 \%$, respectively. As well, $\gamma$-terpinene decreased in ECEO from $21.65 \%$ to 17.41 and $20.23 \%$, with decreased ratio $19.58 \%$ and $6.56 \%$ whereas, SCEO decreased from $17.64 \%$ to $6.00 \%$ and $13.01 \%$ with decreased ratio $65.99 \%$ and $26.25 \%$, respectively. On the other hand, $p$-cymene increased in ECEO from $5.56 \%$ to $11.12 \%$ and $7.65 \%$ with increased ratio $50.00 \%$ and $27.32 \%$ while SCEO increased from $3.52 \%$ to $17.83 \%$ and $12.98 \%$ with increased ratio $80.26 \%$ and $72.88 \%$, respectively.

However, the cuminaldehyde (4 - isopropyl benzaldehyde) was increased gradually at room temperature and refrigerator during storage. The cuminaldehyde increased in ECEO from $22.74 \%$ to $29.02 \%$ and $24.10 \%$ with rate of growth $21.64 \%$ 
Table 3. Physicochemical properties of Egyptian and Syrian cumin essential oils after distillation at different periods.

\begin{tabular}{|c|c|c|c|c|c|c|c|c|}
\hline \multirow[b]{2}{*}{ Specifications } & \multicolumn{4}{|c|}{ Egyptian } & \multicolumn{4}{|c|}{ Syrian } \\
\hline & $\mathbf{F}_{1}$ & $F_{2}$ & $F_{3}$ & $\begin{array}{c}\text { Total } \\
\text { fractions }\end{array}$ & $F_{1}$ & $\mathbf{F}_{2}$ & $F_{3}$ & $\begin{array}{c}\text { Total } \\
\text { fractions }\end{array}$ \\
\hline Specific gravity & $0.9154 \pm 0.11^{\mathrm{a}}$ & $0.8879 \pm 0.09^{\mathrm{b}}$ & $0.8828 \pm 0.15^{\mathrm{b}}$ & $0.9126 \pm 0.12$ & $0.9228 \pm 0.12^{\mathrm{a}}$ & $0.8930 \pm 0.16^{\mathrm{b}}$ & $0.8792 \pm 0.11^{\mathrm{b}}$ & $0.9208 \pm 0.13$ \\
\hline $\begin{array}{l}\text { Refractive } \\
\text { index }\end{array}$ & $1.5007 \pm 0.05^{\mathrm{a}}$ & $1.4905 \pm 0.03^{\mathrm{b}}$ & $1.4881 \pm 0.01^{\mathrm{b}}$ & $1.4997 \pm 0.04$ & $1.5480 \pm 0.02^{\mathrm{a}}$ & $1.4939 \pm 0.05^{\mathrm{b}}$ & $1.4872 \pm 0.11^{\mathrm{b}}$ & $1.5447 \pm 0.04$ \\
\hline Optical rotation & $+4^{\circ} 20^{\prime} \pm 0.01^{\mathrm{a}}$ & $+3^{\circ} 50^{\prime} \pm 0.00^{\mathrm{b}}$ & $+2^{\circ} 80^{\prime} \pm 0.03^{\mathrm{c}}$ & $+4^{\circ} 10^{\prime} \pm 0.01$ & $+4^{\circ} 10^{\prime} \pm 0.00^{\mathrm{a}}$ & $+6^{\circ} 30^{\prime} \pm 0.03^{\mathrm{c}}$ & $+8^{\circ} 10^{\prime} \pm 0.03^{\mathrm{b}}$ & $+4^{\circ} 28^{\prime} \pm 0.02$ \\
\hline Acid number & $0.87 \pm 0.12^{\mathrm{c}}$ & $2.99 \pm 0.13^{\mathrm{b}}$ & $4.40 \pm 0.21^{\mathrm{a}}$ & $1.11 \pm 0.14$ & $1.10 \pm 0.17^{\mathrm{c}}$ & $2.83 \pm 0.12^{\mathrm{b}}$ & $3.53 \pm 0.28^{\mathrm{a}}$ & $1.21 \pm 0.18$ \\
\hline
\end{tabular}

All analysis done at $20^{\circ} \mathrm{C}$

abc Values in the same row for each attribute followed by different letters are significantly different $(\mathrm{P}<0.05)$

Mean $\pm \mathrm{SD}, \mathrm{n}=3$. 

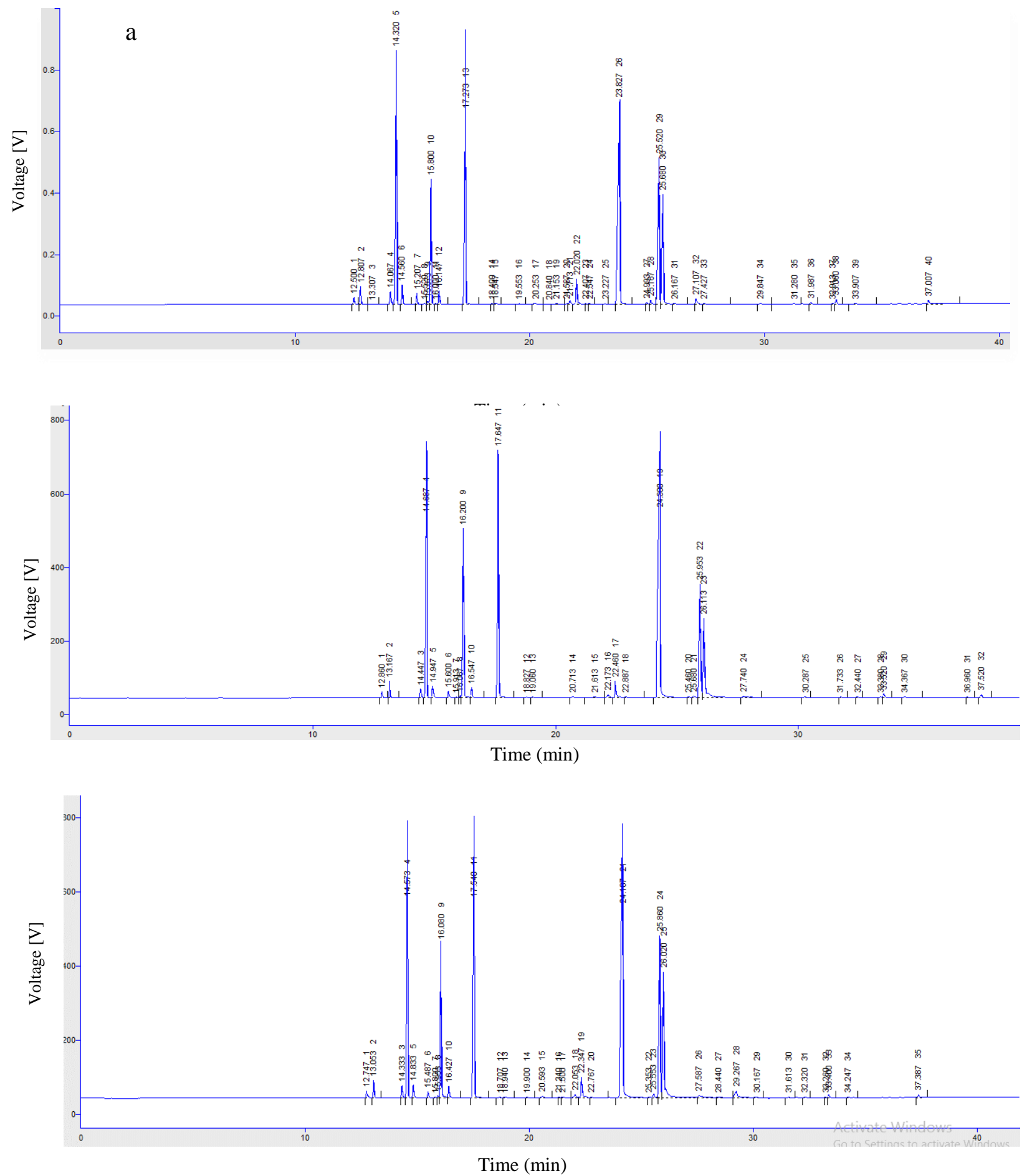

Figure 3. GC-volatile compounds of Egyptian cumin essential oil (control; a) and stored 12 months at room temperature $\left(25 \pm 1^{\circ} \mathrm{C}\right)(\mathrm{b})$ and at refrigerator $\left(4 \pm 1^{\circ} \mathrm{C}\right)(\mathrm{c})$. 

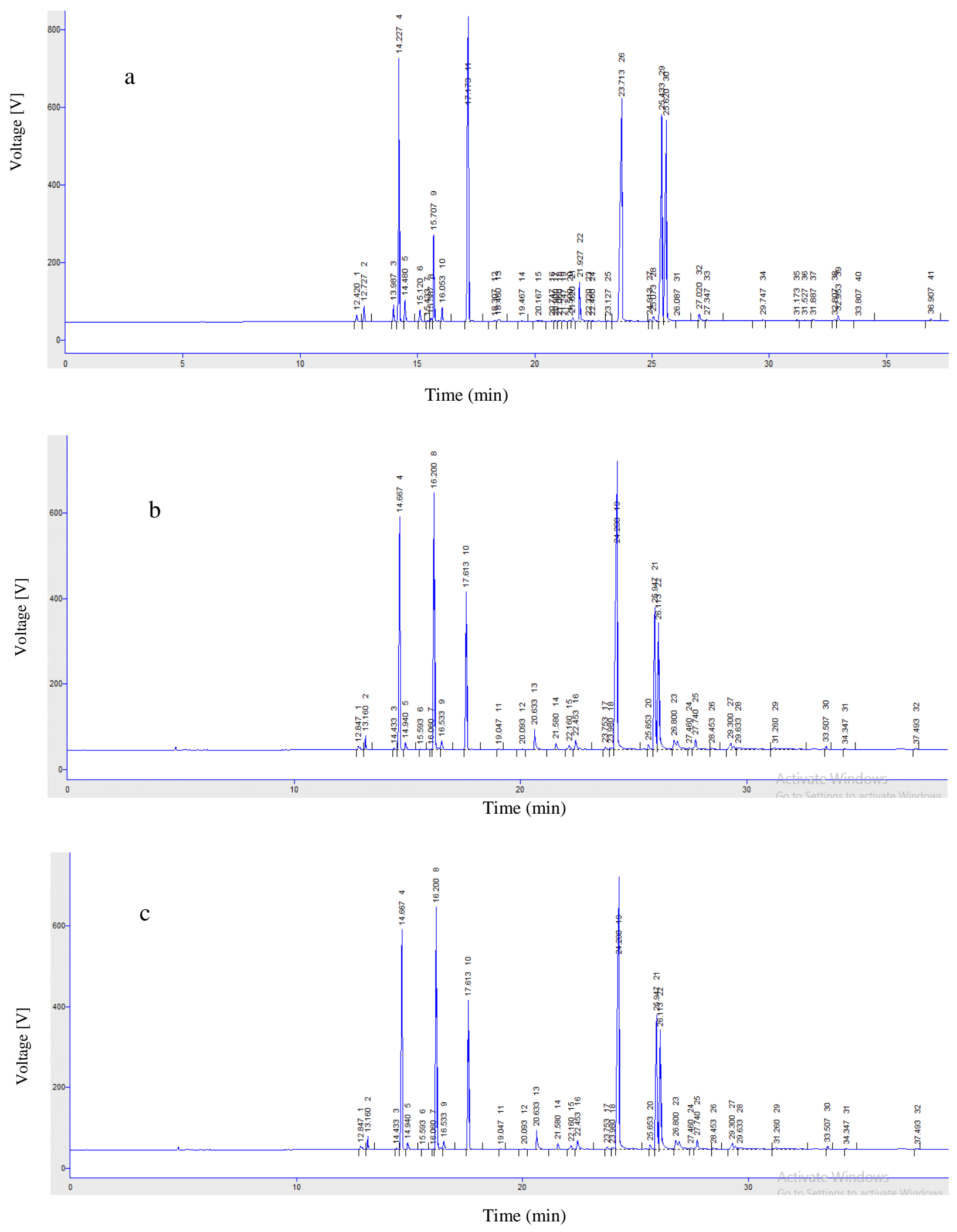

Figure 4. GC-volatile compounds of Syrian cumin essential oil (control; a) and stored 12 months at room temperature $\left(25 \pm 1^{\circ} \mathrm{C}\right)(\mathrm{b})$ and at refrigerator $\left(4 \pm 1^{\circ} \mathrm{C}\right)(\mathrm{c})$. 
Table 4. Volatile compounds of Egyptian cumin essential oils during storage up to 12 months at room temperature and refrigerator.

\begin{tabular}{|c|c|c|c|c|c|c|c|c|c|}
\hline \multirow{3}{*}{ NO } & \multirow{3}{*}{ Components } & \multirow{3}{*}{ RT } & \multirow{3}{*}{$\begin{array}{c}\text { Control } \\
(\%)\end{array}$} & \multicolumn{6}{|c|}{ Storage conditions (\%) } \\
\hline & & & & \multicolumn{3}{|c|}{$\begin{array}{l}\text { Room temperature } \\
\left(25 \pm 1^{\circ} \mathrm{C}\right)\end{array}$} & \multicolumn{3}{|c|}{$\begin{array}{c}\text { Refrigerator } \\
\left(4 \pm 1^{\circ} \mathrm{C}\right)\end{array}$} \\
\hline & & & & 3 & 6 & 12 & 3 & 6 & 12 \\
\hline 1 & Alpha thujene & 12.74 & 0.36 & 0.36 & 0.34 & 0.29 & 0.36 & 0.36 & 0.36 \\
\hline 2 & $\alpha$-pinene & 13.04 & 0.91 & 0.91 & 0.90 & 0.86 & 0.91 & 0.91 & 0.90 \\
\hline 3 & Sabinene & 14.32 & 0.80 & 0.79 & 0.78 & 0.71 & 0.80 & 0.79 & 0.78 \\
\hline 4 & $\beta$-pinene & 14.50 & 16.47 & 15.58 & 14.50 & 12.57 & 16.14 & 16.00 & 15.99 \\
\hline 5 & $\beta$ - myrcene & 14.82 & 1.07 & 1.07 & 1.00 & 0.98 & 1.07 & 1.07 & 1.05 \\
\hline 6 & $\alpha$-phellendrene & 15.46 & 0.57 & 0.57 & 0.44 & 0.34 & 0.57 & 0.55 & 0.51 \\
\hline 7 & $P$-cymene & 16.06 & 5.56 & 7.35 & 9.89 & 11.12 & 6.01 & 6.87 & 7.65 \\
\hline 8 & d-Limonene & 16.42 & 0.80 & 0.79 & 0.74 & 0.710 & 0.80 & 0.79 & 0.79 \\
\hline 9 & $\gamma$-terpinene & 17.52 & 21.65 & 19.99 & 19.33 & 17.41 & 21.38 & 20.63 & 20.23 \\
\hline 10 & Linalool & 18.70 & 0.06 & 0.06 & 0.06 & 0.10 & 0.06 & 0.06 & 0.06 \\
\hline 11 & Beta-ocimene & 18.94 & 0.07 & 0.08 & 0.09 & 0.10 & 0.07 & 0.08 & 0.08 \\
\hline 12 & Terpinene - 4- ol & 22.04 & 0.27 & 0.26 & 0.24 & 0.07 & 0.26 & 0.26 & 0.25 \\
\hline 13 & 3-para menthanal- 7-al & 22.33 & 1.74 & 1.34 & 0.65 & 0.32 & 1.65 & 1.56 & 1.32 \\
\hline 14 & Cuminaldehyde & 24.14 & 22.74 & 25.94 & 26.89 & 29.02 & 23.05 & 23.41 & 24.10 \\
\hline 15 & 1,3 para mentha diene -7 -al & 25.83 & 13.01 & 13.86 & 14.00 & 14.75 & 13.11 & 13.19 & 13.45 \\
\hline 16 & 1,4 para Mentha diene -7 -al & 25.99 & 9.00 & 9.11 & 9.29 & 9.57 & 9.00 & 9.06 & 9.10 \\
\hline 17 & Cuminol & 27.56 & 0.45 & 0.45 & 0.46 & 0.46 & 0.45 & 0.45 & 0.46 \\
\hline 18 & $\beta$-caryophellene & 33.38 & 0.28 & 0.28 & 0.28 & 0.29 & 0.28 & 0.28 & 0.29 \\
\hline \multicolumn{10}{|c|}{ Grouped components (\%) } \\
\hline & Monoterpene hydrocarbons & & 48.19 & 47.41 & 47.92 & 44.99 & 48.04 & 47.97 & 48.26 \\
\hline & Oxygenated monoterpenes & & 47.28 & 51.04 & 51.62 & 54.29 & 47.59 & 48.01 & 48.76 \\
\hline & Others & & 0.28 & 0.28 & 0.28 & 0.29 & 0.28 & 0.28 & 0.29 \\
\hline \multicolumn{10}{|c|}{ Total aldehydes (\%) } \\
\hline & Total aldehyde & & 46.49 & 50.25 & 50.83 & 53.66 & 46.81 & 47.22 & 47.97 \\
\hline \multicolumn{10}{|c|}{ Total identified compounds (\%) } \\
\hline & Total & & 95.81 & 98.79 & 99.88 & 99.67 & 95.97 & 96.32 & 97.37 \\
\hline
\end{tabular}

and $5.64 \%$ while SCEO the cuminaldehyde increased from $18.96 \%$ to $47.19 \%$ and $24.77 \%$ with rate of growth $59.82 \%$ and $23.46 \%$, respectively. This increase is due to high molecular weight of cuminaldehyde and to the breakdown of some terpenes during storage period. These results agreement with those reported by Mehdizadeh et al., (2017).

Results, confirmed that the stability of Egyptian cumin oil during storage is better than Syrian. In addition, the storage of CEO in refrigerator is relatively better than room temperature.

From the results presented in Table (6), the physical and chemical characteristics were slightly affected by storage conditions. The specific gravity, refractive index, and optical rotation were increased gradually during storage time. This change was a significant in Syrian cumin oil than Egyptian, especially at room temperature, due to degradation of low molecular weight components. While, the acid numbe was increasing during storage time especially in Syrian cumin oil at room temperature because of intensified the oxidative reactions and increase in free fatty acids (Almeida et al., 2018).

In general, there are many factors affecting on the yield and chemical composition of cumin in different regions. This difference in chemical composition of the oils depends on various factors, including plant part, harvest time, type of cultivar, storage conditions, climatic effects on the plants, seasonal changes even sunlight duration, geographic origin and processing of plant materials such as extraction methods and the conditions of analysis (Zhang et al., 2011; and Roustakhiz and Raissi, 2017). 
Table 5. Volatile compounds of Syrian cumin essential oils during storage up to 12 months at room temperature and refrigerator.

\begin{tabular}{|c|c|c|c|c|c|c|c|c|c|}
\hline \multirow{3}{*}{ NO } & \multirow{3}{*}{ Components } & \multirow{3}{*}{ RT } & \multirow{3}{*}{$\begin{array}{c}\text { Control } \\
(\%)\end{array}$} & \multicolumn{6}{|c|}{ Storage conditions $(\%)$} \\
\hline & & & & \multicolumn{3}{|c|}{$\begin{array}{c}\text { Room temperature } \\
\left(25 \pm 1^{\circ} \mathrm{C}\right)\end{array}$} & \multicolumn{3}{|c|}{$\begin{array}{c}\text { Refrigerator } \\
\left(4 \pm 1^{\circ} \mathrm{C}\right)\end{array}$} \\
\hline & & & & 3 & 6 & 12 & 3 & 6 & 12 \\
\hline 1 & Alpha thujene & 12.81 & 0.30 & 0.20 & 0.18 & 0.13 & 0.29 & 0.28 & 0.25 \\
\hline 2 & $\alpha$ - pinene & 13.12 & 0.57 & 0.46 & 0.39 & 0.15 & 0.57 & 0.55 & 0.53 \\
\hline 3 & Sabinene & 14.39 & 0.77 & 0.76 & 0.75 & 0.51 & 0.77 & 0.76 & 0.68 \\
\hline 4 & $\beta$ - pinene & 14.64 & 13.41 & 12.77 & 11.10 & 9.26 & 13.34 & 12.68 & 12.29 \\
\hline 5 & $\beta$ - myrcene & 14.89 & 1.03 & 0.37 & 0.31 & 0.17 & 0.99 & 0.80 & 0.66 \\
\hline 6 & $\alpha$-phellendrene & 15.51 & 0.42 & 0.34 & 0.28 & 0.11 & 0.39 & 0.38 & 0.33 \\
\hline 6 & $P$-cymene & 16.15 & 3.52 & 13.40 & 15.05 & 17.83 & 10.57 & 11.50 & 12.98 \\
\hline 7 & d-Limonene & 16.49 & 0.76 & 0.76 & 0.61 & 0.27 & 0.75 & 0.68 & 0.64 \\
\hline 8 & $\gamma$-terpinene & 17.59 & 17.64 & 11.11 & 8.95 & 6.00 & 15.01 & 13.94 & 13.01 \\
\hline 9 & Linalool & 18.78 & 0.07 & 0.04 & 0.03 & 0.00 & 0.06 & 0.05 & 0.05 \\
\hline 10 & Cis- sabinene hydrate & 19.01 & 0.16 & 0.16 & 0.15 & 0.14 & 0.16 & 0.16 & 0.15 \\
\hline 11 & Terpinene - 4- ol & 22.12 & 0.25 & 0.22 & 0.20 & 0.16 & 0.25 & 0.24 & 0.23 \\
\hline 12 & 3-para menthanal- 7-al & 22.41 & 2.40 & 1.02 & 0.74 & 0.57 & 2.31 & 2.09 & 1.89 \\
\hline 13 & Cuminaldehyde & 24.25 & 18.96 & 31.69 & 35.54 & 47.19 & 21.80 & 22.89 & 24.77 \\
\hline 14 & 1,3 para mentha diene -7 -al & 25.90 & 19.57 & 14.67 & 12.77 & 9.22 & 17.85 & 17.22 & 16.46 \\
\hline 15 & 1,4 para Mentha diene -7 -al & 26.06 & 19.58 & 11.09 & 9.45 & 6.42 & 14.01 & 13.80 & 13.00 \\
\hline 16 & Cuminol & 27.68 & 0.04 & 0.04 & 0.05 & 0.06 & 0.04 & 0.04 & 0.04 \\
\hline 17 & $\beta$-caryophellene & 33.46 & 0.24 & 0.24 & 0.25 & 0.26 & 0.24 & 0.24 & 0.25 \\
\hline \multicolumn{10}{|c|}{ Grouped components (\%) } \\
\hline & $\begin{array}{l}\text { Monoterpene } \\
\text { hydrocarbons }\end{array}$ & & 38.42 & 40.16 & 37.62 & 34.41 & 42.68 & 41.59 & 41.35 \\
\hline & Oxygenated monoterpenes & & 60.97 & 58.89 & 58.90 & 63.76 & 56.41 & 56.44 & 56.54 \\
\hline & Others & & 0.24 & 0.24 & 0.25 & 0.26 & 0.24 & 0.24 & 0.25 \\
\hline \multicolumn{10}{|c|}{ Total aldehydes (\%) } \\
\hline & Total aldehyde & & 60.51 & 58.47 & 58.50 & 63.40 & 55.96 & 56.01 & 56.12 \\
\hline \multicolumn{10}{|c|}{ Total identified compounds (\%) } \\
\hline & Total & & 99.70 & 99.33 & 96.79 & 98.43 & 99.38 & 98.32 & 98.19 \\
\hline
\end{tabular}

RT: Retention time

Table 6. Physicochemical properties of Egyptian and Syrian cumin essential oils during storage up to12 months at room temperature and refrigerator.

\begin{tabular}{|c|c|c|c|c|c|c|}
\hline $\begin{array}{l}\text { Cumin } \\
\text { Origen }\end{array}$ & $\begin{array}{c}\text { Storage } \\
\text { conditions }\end{array}$ & $\begin{array}{l}\text { Storage time } \\
\text { (months) }\end{array}$ & $\begin{array}{l}\text { Specific } \\
\text { gravity }\end{array}$ & $\begin{array}{l}\text { Refractive } \\
\text { index }\end{array}$ & $\begin{array}{c}\text { Optical } \\
\text { rotation }\end{array}$ & Acid number \\
\hline \multirow{7}{*}{ 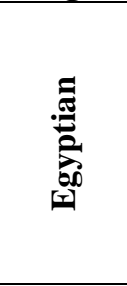 } & Control & 0 & $0.915 \pm 0.15^{\mathrm{d}}$ & $1.5007 \pm 0.03^{\mathrm{d}}$ & $+4^{\circ} 25^{\prime} \pm 0.07^{\mathrm{a}}$ & $0.87 \pm 0.29^{\mathrm{h}}$ \\
\hline & \multirow{3}{*}{$\begin{array}{c}\text { Room } \\
\left(25 \pm 1^{\circ} \mathrm{C}\right)\end{array}$} & 3 & $0.916 \pm 0.13^{\mathrm{d}}$ & $1.5030 \pm 0.04^{c}$ & $+4^{\circ} 25^{\prime} \pm 0.03^{\mathrm{a}}$ & $9.69 \pm 0.15^{\mathrm{e}}$ \\
\hline & & 6 & $0.921 \pm 0.11^{\mathrm{c}}$ & $1.5040 \pm 0.10^{\mathrm{c}}$ & $+4^{\circ} 30^{\prime} \pm 0.05^{\mathrm{a}}$ & $10.62 \pm 0.21^{\mathrm{e}}$ \\
\hline & & 12 & $0.929 \pm 0.17^{\mathrm{c}}$ & $1.5056 \pm 0.09^{c}$ & $+4^{\circ} 35^{\prime} \pm 0.01^{\mathrm{a}}$ & $12.94 \pm 0.25^{\mathrm{e}}$ \\
\hline & \multirow{3}{*}{$\begin{array}{l}\text { Refrigerator } \\
\quad\left(4 \pm 1^{\circ} \mathrm{C}\right)\end{array}$} & 3 & $0.915 \pm 0.11^{\mathrm{d}}$ & $1.5012 \pm 0.06^{\mathrm{a}}$ & $+4^{\circ} 25^{\prime} \pm 0.03^{\mathrm{a}}$ & $3.10 \pm 0.05^{\mathrm{g}}$ \\
\hline & & 6 & $0.919 \pm 0.09^{c}$ & $1.5018 \pm 0.09^{\mathrm{a}}$ & $+4^{\circ} 40^{\prime} \pm 0.01^{\mathrm{a}}$ & $4.58 \pm 0.08^{\mathrm{f}}$ \\
\hline & & 12 & $0.922 \pm 0.09^{\mathrm{c}}$ & $1.5031 \pm 0.05^{\mathrm{c}}$ & $+4^{\circ} 95^{\prime} \pm 0.04^{\mathrm{a}}$ & $4.84 \pm 0.18^{f}$ \\
\hline \multirow{7}{*}{ 馬 } & Control & 0 & $0.922 \pm 0.07^{\mathrm{c}}$ & $1.5080 \pm 0.03^{b}$ & $+4^{\circ} 10^{\prime} \pm 0.11^{a}$ & $1.10 \pm 0.13^{\mathrm{h}}$ \\
\hline & \multirow{3}{*}{$\begin{array}{c}\text { Room } \\
\left(25 \pm 1^{\circ} \mathrm{C}\right)\end{array}$} & 3 & $0.959 \pm 0.11^{\mathrm{b}}$ & $1.5083 \pm 0.02^{b}$ & $+3^{\circ} 30^{\prime} \pm 0.04^{b}$ & $43.26 \pm 0.30^{c}$ \\
\hline & & 6 & $0.965 \pm 0.14^{\mathrm{a}}$ & $1.5099 \pm 0.12^{b}$ & $+3^{\circ} 10^{\prime} \pm 0.08^{b}$ & $48.06 \pm 0.27^{\mathrm{b}}$ \\
\hline & & 12 & $0.978 \pm 0.17^{\mathrm{a}}$ & $1.5124 \pm 0.11^{\mathrm{a}}$ & $+2^{\circ} 40^{\prime} \pm 0.03^{b}$ & $57.40 \pm 0.28^{\mathrm{a}}$ \\
\hline & \multirow{3}{*}{$\begin{array}{l}\text { Refrigerator } \\
\quad\left(4 \pm 1^{\circ} \mathrm{C}\right)\end{array}$} & 3 & $0.954 \pm 0.09^{\mathrm{b}}$ & $1.5081 \pm 0.08^{a}$ & $+3^{\circ} 80^{\prime} \pm 0.02^{b}$ & $39.22 \pm 0.16^{\mathrm{d}}$ \\
\hline & & 6 & $0.957 \pm 0.04^{\mathrm{b}}$ & $1.5111 \pm 0.04^{\mathrm{a}}$ & $+3^{\circ} 50^{\prime} \pm 0.01^{b}$ & $41.78 \pm 0.22^{\mathrm{c}}$ \\
\hline & & 12 & $0.959 \pm 0.09^{\mathrm{b}}$ & $1.5189 \pm 0.02^{\mathrm{a}}$ & $+3^{\circ} 10^{\prime} \pm 0.03^{b}$ & $43.30 \pm 0.19^{\mathrm{c}}$ \\
\hline
\end{tabular}

All analysis done at $20^{\circ} \mathrm{C}$

${ }^{a b c}$ Values in the same row for each attribute followed by different letters are significantly different $(\mathrm{P}<0.05)$.

Mean $\pm \mathrm{SD}, \mathrm{n}=3$. 


\subsection{Sensory evaluation of cumin essential oil during storage}

Temperature and refrigerator are presented in (Table 7). Results indicate that the odor and color were decreased and unacceptable that leads to consumer's rejection. In general, no difference was recorded at zero time of storage for both Egyptian and Syrian cumin oil $(p \geq 0.05)$. The scores of odor and colors decreased with the time of storage increased, at the first 3 months of storage no significant differences were noticed in ECEO, while SCEO record slight significant differences. While, after storage oil for 6 months the ECEO stored in refrigerator revealed the lowest score of difference and significantly results at $(P \leq 0.05)$ compared with room temperature. Whereas, SCEO after storage for 6 months at room and refrigerator temperature record high score of difference in color and odor. After storage oil for 12 months the odor and color in ECEO became rancid and unacceptable while SCEO became off odor and mostly unacceptable especially oil storage at room temperature, which was indicative of oil degradation of some components and increase of free acids. The samples were quite stable in odor and color for 3 months of storage at room and refrigerator temperature for both ECEO and SCEO while some differences became apparent after 6 months of storage especially SCEO and room temperature. After 12 months of storage, the color of SCEO was dark brown at room temperature and refrigerator, and had rejected odor (off odor) while the color of ECEO was brownish yellow at room temperature and yellow in refrigerator, and had burned odor at room temperature and spicy odor in refrigerator. Thus, the acceptance degree of the oil decreased during storage especially at room temperature, addition the odor and color of ECEO was more stability than SCEO.

Table 7. Sensory responses for color and odor of Egyptian and Syrian cumin essential oil during storage for 12 months at room temperature and refrigerator.

\begin{tabular}{lllcccc}
\hline \multirow{2}{*}{ Attributes } & \multirow{2}{*}{ category } & \multirow{2}{*}{ Temperature } & \multicolumn{4}{c}{ Storage period (months) } \\
\cline { 3 - 6 } Color & & $\mathbf{0}$ & $\mathbf{3}$ & $\mathbf{6}$ & $\mathbf{1 2}$ \\
& \multirow{2}{*}{ Egyptian } & Room & $9 \pm 0.09^{\mathrm{a}}$ & $8 \pm 0.07^{\mathrm{b}}$ & $7.6 \pm 0.11^{\mathrm{b}}$ & $5 \pm 0.03^{\mathrm{b}}$ \\
& & Refrigerator & $9 \pm 0.13^{\mathrm{a}}$ & $9 \pm 0.12^{\mathrm{a}}$ & $8.5 \pm 0.18^{\mathrm{a}}$ & $8.1 \pm 0.01^{\mathrm{a}}$ \\
& \multirow{3}{*}{ Syrian } & Room & $9 \pm 0.10^{\mathrm{a}}$ & $6 \pm 0.13^{\mathrm{c}}$ & $4.4 \pm 0.15$ & $1.4 \pm 0.07^{\mathrm{d}}$ \\
& & Refrigerator & $9 \pm 0.08^{\mathrm{a}}$ & $7 \pm 0.09$ & $5.2 \pm 0.06^{\mathrm{c}}$ & $2.2 \pm 0.13^{\mathrm{c}}$ \\
& \multirow{2}{*}{ Egyptian } & Room & $9 \pm 0.14^{\mathrm{a}}$ & $9 \pm 0.11^{\mathrm{a}}$ & $8.3 \pm 0.10^{\mathrm{a}}$ & $4.6 \pm 0.09^{\mathrm{b}}$ \\
& & Refrigerator & $9 \pm 0.11^{\mathrm{a}}$ & $9 \pm 0.04^{\mathrm{a}}$ & $8.8 \pm 0.06^{\mathrm{a}}$ & $8.3 \pm 0.05^{\mathrm{a}}$ \\
& \multirow{2}{*}{ Syrian } & Room & $8 \pm 0.12^{\mathrm{b}}$ & $7 \pm 0.07^{\mathrm{c}}$ & $2.6 \pm 0.05^{\mathrm{c}}$ & $N D$ \\
& & Refrigerator & $8 \pm 0.16^{\mathrm{b}}$ & $8 \pm 0.13^{\mathrm{b}}$ & $3.7 \pm 0.04^{\mathrm{b}}$ & $N D$ \\
\hline
\end{tabular}

abc Values in the same row for each attribute followed by different letters are significantly different $(\mathrm{P}<0.05)$.

Mean $\pm \mathrm{SD}, \mathrm{n}=3$.

\section{Conclusion}

The present study has clearly demonstrated that the distillation time which run as 3 fractions $\left(F_{1}\right.$ : first $6 \mathrm{~h}$; $\mathrm{F}_{2}$ : between 7 and $8 \mathrm{~h}$; and $\mathrm{F}_{3}$ : between 9 and $12 \mathrm{~h}$ effected on the yield and quality of CEOs. The yield percentage of Egyptian cumin essential oil (ECEO) was $(5.59 \%)$ and Syrian cumin essential oil (SCEO) was $(3.36 \%)$. The most oil obtained at first $6 \mathrm{~h}\left(\mathrm{~F}_{1}\right)$ of distillation ( $\sim 90 \%)$ with best sensory (color and odor) and quality, followed by $\mathrm{F}_{2}(\sim 7.50 \%)$ and $\mathrm{F}_{3}(\sim 2.50 \%)$. The main compounds in CEOs were cuminaldehydes,1,3para-mentha diene-7-al, 1,4paramentha diene-7-al, $\beta$-pinene, $\beta$-myrcene, $p$-cymene, $\mathrm{d}$ limonene, and $\gamma$-terpinene. Moreover, the results demonstrated that storage at different temperature influences on the quality and compositions of cumin oil especially at room temperature. During the storage the components such as $\alpha$-pinene, $\beta$-pinene, $\beta$-myrcene, $d$ limonene and $\gamma$-terpinene were decreased due to evaporating and degradation during the storage, while $p$-cymene was increased however, cuminaldehyde increased during 12 months at room temperature compared with refrigerator, as well, the CEOs, which was Stored in a refrigerator possess its primary quality better compared with stored at room temperature. The sensory attributes of CEOs stored at refrigerator was significantly higher than room temperature. These results also confirmed that ECEO is better than SCEO during processing and more stable during storage.

\section{Acknowledgment}

The authors express their sincere gratitude to Phatrade Essential Oil Company for providing the facilities and all the support provided.

\section{References}

Aćimović, M.G.; Tešević, V.; Mara, D.; Cvetković, M.; Stanković, J.; and Filipović, V. 2016. The analysis of cumin seeds essential oil and total polyphenols from postdestillation waste material. J. Advanced Technologies 5(1): 23-30. 
Al-Hashemi, F.H.Y. 2014. Chromatographic separation and identification of some volatile oils, organic acids and phenols from the seeds of cuminum cyminum growing in Iraq. International $\mathbf{J}$. of Recent Research and Applied Studies. 19(1): 80 90.

Allahghadri, T.; Rasooli, I.; Owlia, P.; Nadooshan, M.J.; Ghazanfari, T.; Taghizadeh, M.; and Astaneh, S.D.A. 2010. Antimicrobial property, antioxidant capacity, and cytotoxicity of essential oil from cumin produced in Iran. J. of Food Sci. 75(2): $54-61$.

Al-Snafi, A.E. 2016. The pharmacological activities of Cuminum cyminum. IOSR J. of Pharmacy. 6(2): 4665.

Al-Zubairi, A.S.; Al-Mamary, M.A.; and AlGhasani, E. 2017. The antibacterial, antifungal, and antioxidant activities of essential oil from different aromatic plants. Glo. Adv. Res. J. Med. Sci. 6(9): 224-233.

A.O.A.C. 2016. Association of Official Analytical Chemists. Official Methods of Analysis. (20 ${ }^{\text {th }}$ Ed.) Maryland, USA.

Atawia, B.A.; Hallabo, S.A.S.; and Morsi, M.K. 1988. Hexane Extraction of Acidified jasmine flowers. Egypt J. Food Sci. 16(1-2): 225-235.

Baser, K.H.C. and Buchbauer, G. 2010. Handbook of Essential oils: Science, Technology, and Applications. Taylor and Francis Group, LLC. USA.

Beis, S.H.; Azcan, N.; Qzek, T.; Kara, M.; and Baser, K.H.C. 2000. The production of essential oil from cumin seeds. J. Chemistry Natural Compounds. 36(3): 265-268.

Bettaieb, I.; Bourgou, S.; Sriti, J.; Msaada, K.; Limam, F.; and Marzouk, B. 2011. Essential oils and fatty acids composition of Tunisian and Indian cumin (Cuminum cyminum L.) seeds: a comparative study. J. Sci Food Agric, 91: 2100-2107.

El-Moshtohory, E.A.E. 2007. Chemical and Microbiological Studies on Some Essential Oils. Ph. D., Department of Food Science, Fac. of Agric, Benha Univ.

Guenther, E. 1961. The Essential oils. Krieger publishing company, USA.

Hashemian, N.; Pirbalouti1, A.G.; Hashemi, M.; Golparvar, A. and Hamedi, B. 2013. Diversity in chemical composition and antibacterial activity of essential oils of cumin (Cuminum cyminum L.) diverse from northeast of Iran. Australian J. of Crop Science. 7(11): 1752-1760.

Ingok, A.M. and Guler, F.K. 2017. Cardamom, Cumin, and Dill Weed Essential Oils: Chemical Compositions, Antimicrobial Activities, and Mechanisms of Action against Campylobacter spp. J. Molecules. 22(7):1191-1204.
Iacobellis, N.S.; LoCantore, P.; Capasso, F.; and Senatore, F. 2005. Antibacterial activity of Cuminum cyminum L. and Carum carvi L. essential oils. Journal of Agricultural and Food Chemistry. 53(1): 57-61.

Li, M.; Tian, S.; Pang, Z.C.; Shi, J.Y.; and Feng, Z.S. 2009. Extraction of Cuminum cyminum essential oil by combination technology of organic solvent with low boiling point and steam distillation. J. of Food Chemistry. 115(3): 1114-1119.

Mehdizadeh, L.; Pirbalouti, A.G.; and Moghaddam, M. 2017. Storage stability of essential oil of cumin (cuminum cyminum L.) as a function of temperature. International J. of Food Properties. 20(2): 17421750 .

Moghaddam, M.; Omidbaigi, R.; and Sefidkon, F. 2007. Changes in content and chemical composition of Tagetes minuta oil at various harvest times. J. Essent. Oil Res. 19(1): 18-20.

Moghaddam, M.; Miran, S.N.K.; Pirbalouti, A.G.; Mehdizadeh, L.; and Ghaderi, Y. 2015. Variation in essential oil composition and antioxidant activity of cumin (Cuminum cyminum L.) fruits during stages of maturity. J. Industrial Crops and Products. 70: 163-169.

Ochoa, H.; Prieto, B.A.; Moorillón, G.V.N.; Mendez, N.G.; and Muñoz, E.S. 2014. Use of essential oils and extracts from spices in meat protection. J. Food Sci. Technol. 51(5): 957-963.

Oroojalian, F.; Kasra-Kermanshahi, R.; Azizi, M.; and Bassami, M. 2010. Phytochemical composition of the essential oils from three Apiaceae species and their antibacterial effects on food-borne pathogens. J. of Food Chem. 120(3): 765-770.

Roustakhiz, J. and Raissi, A. 2017. Properties, cultivation method and requirements of cumin (Cuminum cyminum L.) - an overview. Intl. J. Farm \& Alli. Sci. 6(1): 24-29.

Rana, V.S. 2014. Chemical composition of the essential oil of cuminum cyminum L. seeds from western India. J. of Medicinal Plants and By-products. 2: 207-210.

Saha, S.; Walia, S.; Kundu, A.; Sharma, K.; Singh, J.; Tripathi, B. and Raina, A. 2016. Compositional and functional difference in cumin (Cuminum cyminumL) essential oil extracted by hydro distillation and SCFE. J. Cogent Food \& Agriculture. 2: 114-166.

Sowbhagya, H.B.; Rao, B.V.S.; and Krishnamurthy, N. 2008. Evaluation of size reduction and expansion on yield and quality of cumin (cuminum cyminum L) seed oil, J. Food Eng. 84: 595-600.

Steel, R.; Torrie, J.; and Dickey, D. 1997. Principles and procedures of statistics: a biometrical approach. $3^{\text {rd }}$ Ed. New York, N.Y.: McGraw-Hill. 
Teneva, D.; Denkova, Z.; Goranov, B.; Denkova, R.; Kostov, G.; Tanasova, T.; and Merdzhanov, P. 2016. Chemical composition and antimicrobial activity of essential oils from black pepper, cumin, coriander and cardamom against some pathogenic microorganisms. Acta Universitatis Cibiniensis Series E: food technology. 2(2): 39-52.

Viuda-Martos, M.; Ruiz-Navajas, Y.; FernándezLópez, J.; and Pérez-Álvarez, J.A. 2008. Antibacterial activity of different essential oils obtained from spices widely used in mediterranean diet. International J. of Food Science and Technology. 43: $526-531$.

Zhang, H.; Shi, Y.; Wei, S.; and Wang Y. 2011. Ultrasonic nebulization extraction coupled with headspace single-drop microextraction of volatile and semi volatile compounds from the seed of Cuminum cyminum L. J. of Talanta. 85(2):10811087.

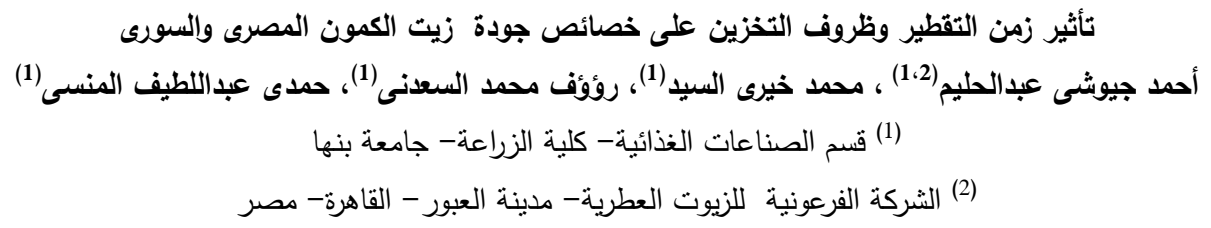

يعتبر زيت الكمون واحدًا من أكثر الزيوت العطرية شيوعا في مجال التصنيع الغذائى لتعزيز طعم ونكهة المنتجات الغذائية وإطالة فترة صلاحيتها والمحافظة

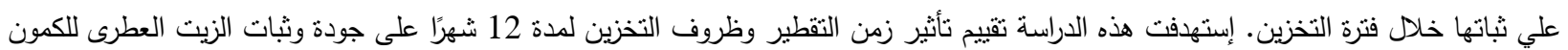
المصرى والسورى. كذلك التعرف على خصائص زيت الكمون خلال عملية التقطير على ثلاث مراحل (فصل تجزيئى)" علما بأن التجربة تمت على نطاق تجارى المرحلة الاولى: أول 6 ساعات من التقطير (ف) ، المرحلة الثانية: الساعتين السابعة والثامنة (فـ)، المرحلة الثالثة (فـ): بداية من الساعها التاسعة حتى الساعة الثانية عشر من زمن التقطير". أيضا دراسة الخصائص الفيزيائية والكيميائية والتركيب الكيميائى ودرجة الثبات لزيت الكمون المخزن

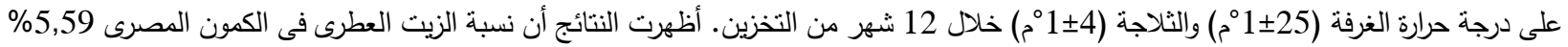

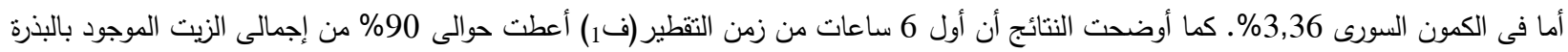

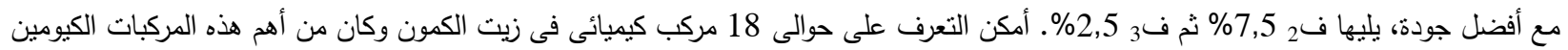

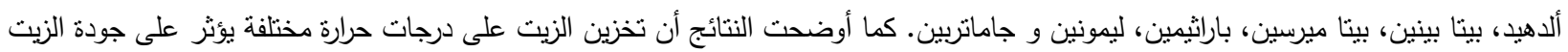
وتركييه الكيماوى وخصوصا النخزين على درجة حرارة الغرفة. حيث لوحظ انخفاض نسبة بعض المركبات متل ألفا بينين- بيتا بينين - بيتا ميرسينليمونين - جاماتربين، بينما زيادة نسبة مركب الباراثميين. كما أثنارت النتائج أن زيت الكمون المحزن على درجة حرارة الثلاجة احتفظ بخصائصه الحسية

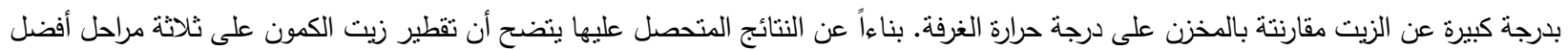
تكنولوجيا، كما أن زيت الكمون المصرى ذات جودة نركيبية عالية، أكثر ثباتاً أثناء التخزين مقارنة بزيت الكمون السورى. الكلمات الدالة: الزيوت العطرية، بذور الكمون، النقطير بالبخار ، الثبات التخزينى، الجودة. 